\title{
PENDIDIKAN KARAKTER ANAK PADA KELUARGA TKW (STUDI KASUS DI DESA NGLANDUNG, KECAMATAN GEGER KABUPATEN MADIUN TAHUN 2015)
}

\author{
Riyayan Dwi Saputro*
}

\begin{abstract}
Abstrak
$\mathrm{P}$ ilihan untuk bekerja menjadi TKW di luar negeri memungkinkan timbulnya permasalahan baru yang muncul, terutama tentang dalam pendidikan karakter pada anak-anak keluarga TKW. Penelitian ini bertujuan untuk mengetahui penanaman nilai-nilai pendidikan karakter anak pada keluarga TKW di Desa Nglandung, Kecamatan Geger Kabupaten Madiun tahun 2015, strategi yang dilakukan dalam memberikan pendidikan karakter anak pada keluarga TKW di Desa Nglandung, Kecamatan Geger Kabupaten Madiun tahun 2015, dan hambatan-hambatan yang ada pada pendidikan karakter anak pada keluarga TKW di Desa Nglandung, Kecamatan Geger Kabupaten Madiun tahun 2015. Penelitian ini dilaksanakan di Desa Nglandung, Kecamatan Geger Kabupaten Madiun mulai bulan September 2015 sampai dengan Januari 2016. Penelitian ini menggunakan pendekatan kualitatif dengan jenis penelitian deskriptif kualitatif. Data yang digunakan dalam penelitian ini meliputi data primer dan data sekunder. Teknik pengumpulan data yang digunakan meliputi wawancara, observasi, dan dokumentasi. Uji keabsahan data menggunakan teknik triangulasi. Penelitian ini menggunakan studi kasus fenomenologi sebagai dasar teorinya. Dalam penelitian ini digunakan analisis data kualitatif. Hasil penelitian menunjukkan bahwa penanaman nilai-nilai pendidikan karakter anak pada keluarga TKW di Desa Nglandung, Kecamatan Geger Kabupaten Madiun sudah dilaksanakan dengan baik. Strategi yang dilakukan dalam memberikan pendidikan karakter anak pada keluarga TKW di Desa Nglandung, Kecamatan Geger Kabupaten Madiun dilakukan melalui pembelajaran, pembiasaan, dan keteladanan. Hambatanhambatan yang ada pada pendidikan karakter anak pada keluarga TKW di Desa Nglandung, Kecamatan Geger Kabupaten Madiun berasal dari aspek internal dan eksternal. Hambatan dari aspek internal adalah tidak adanya ibu disamping anak-anak dalam waktu yang lama membuat anak merasa sedih, anak merasakan kangen kepada ibunya, ayah dalam mendidik terlalu tegas bahkan terkadang dengan marah dan terkadang acuh tak acuh atau masa bodoh terhadap anak, serta anak banyak mengalami perubahan perilaku karena kurangnya pembinaan, pendampingan, perhatian, dan kasih sayang dari ibu. Hambatan dari aspek eksternal berasal dari lingkungan masyarakat maupun lingkungan pertemanan atau teman sebaya, khususnya yang berkaitan dengan pergaulan dengan teman, prestasi belajar yang tidak maksimal, dan kesulitan belajar dengan penuh konsentrasi.
\end{abstract}

Kata Kunci: pendidikan karakter, keluarga TKW

* Mahasiswa Program Studi Pendidikan Pancasila dan Kewarganegaraan, FPIPS IKIP PGRI Madiun. 


\section{PENDAHULUAN}

Bangsa Indonesia pada saat ini dihadapkan pada krisis karakter yang cukup memprihatinkan. Fenomena tentang meningkatnya kenakalan remaja dalam masyarakat, seperti perkelahian antar pelajar, perilaku seks pranikah di kalangan remaja, dan berbagai kasus dekadensi moral lainnya merupakan salah saru indikator dari krisis karakter pada masyarakat, khususnya remaja. Untuk itu, krisis karakter sudah waktunya untuk diatasi secara struktural. Penanganan krisis karakter haruslah dimulai dari pemahaman akan penyebab krisis itu sendiri salah satunya dengan menanamkan pendidikan budi pekerti atau karakter mulai sejak dini.

Fathurrohman, dkk. (2013: 116) mengemukakan bahwa "Pendidikan karakter tidak hanya membuat seorang anak mempunyai akhlak mulia, akan tetapi juga dapat meningkatkan kualitas akademiknya. Hubungan antara keberhasilan pendidikan karakter dengan keberhasilan akademik dapat menumbuhkan suasana sekolah yang menyenangkan dan proses belajar mengajar yang kondusif." Oleh sebab itu, pembentukan karakter tidak bisa dipisahkan dari kehidupan. Diperlukan kepedulian oleh berbagai pihak baik oleh pemerintah, sekolah, masyarakat, maupun keluarga. Dalam keluarga, anak dilahirkan, dirawat, dibesarkan dan proses pendidikan berawal. Orang tua adalah guru pertama dan utama bagi anak. Sejak anak dilahirkan mulai belajar berbicara, dan mengenal untuk berinteraksi dan bersosialisasi dengan anggota keluarga terlebih dahulu. Masa anak-anak yang hanya berinteraksi dan bersosialisasi dengan anggota keluarga, ini adalah saat yang tepat bagi orang tua untuk membentuk karakter seorang anak. Orang tualah yang merupakan teladan bagi anak.

Pada keluarga tenaga kerja wanita (TKW) yang bekerja di luar negeri, kebersamaan keluarga tentu saja tidak terjadi. Hal ini menjadikan lingkungan yang kurang kondusif dalam pembentukan karakter anak. Fungsi ibu pada keluarga yang ibunya bekerja sebagai tenaga kerja wanita (TKW) di luar negeri tidak dapat berjalan ideal. Walaupun dalam keluarga tersebut peran ibu dapat 
digantikan anggota keluarga lain seperti ayah, kakak, bibi, atau nenek, namun fungsi ibu tidak dapat berjalan secara optimal. Sebagai akibat dari kurang optimalnya fungsi ibu, anak kehilangan perhatian serta kontrol atas perilaku yang mereka lakukan. Hal ini akan berpengaruh terhadap perkembangan anak. Istri yang juga sebagai seorang ibu bekerja menjadi TKW di luar negeri menyebabkan anak jauh dari ibunya. Pilihan untuk bekerja menjadi TKW di luar negeri memungkinkan timbulnya permasalahan baru yang muncul, terutama tentang dalam pendidikan karakter pada anak-anak keluarga TKW tersebut. Pendidikan karakter yang seharusnya dimulai dari keluarga terutama ibu di rumah tidak dapat berjalan optimal, yang menanamkan pendidikan karakter pada anak yang ditinggalkan ibunya menjadi TKW digantikan oleh anggota keluarga lain. Berdasarkan pernyataan di atas maka penulis ingin mengadakan penelitian dengan judul "Pendidikan Karakter Anak Pada Keluarga TKW (Studi Kasus di Desa Nglandung, Kecamatan Geger Kabupaten Madiun Tahun 2015).” Adapun tujuan penelitian ini adalah untuk mengetahui penanaman nilainilai pendidikan karakter anak pada keluarga TKW di Desa Nglandung, Kecamatan Geger Kabupaten Madiun tahun 2015, strategi yang dilakukan dalam memberikan pendidikan karakter anak pada keluarga TKW di Desa Nglandung, Kecamatan Geger Kabupaten Madiun tahun 2015, serta hambatan-hambatan yang ada pada pendidikan karakter anak pada keluarga TKW di Desa Nglandung, Kecamatan Geger Kabupaten Madiun tahun 2015.

\section{KAJIAN TEORI}

\section{Pendidikan Karakter dalam Keluarga}

Menurut Narwanti (2011: 1) "karakter berasal dari bahasa Yunani kharakter yang berakar dari diksi kharassein yang berarti memahat atau mengukir (to inscribe/to engrave), sedangkan dalam bahasa Latin karakter bermakna membedakan tanda." Dalam Bahasa Indonesia, karakter dapat diartikan sebagai sifatsifat kejiwaan/tabiat/watak. Secara istilah terdapat dua pengertian, pertama karakter menunjukkan bagaimana seseorang bertingkah laku, apabila seseorang berperilaku tidak jujur, kejam, atau tidak rukun, maka 
orang tersebut perwujudan sebagai karakter jelek, sebaliknya apabila seseorang berperilaku jujur, suka menolong, maka orang tersebut perwujudan sebagai karakter mulia.

Plato (dalam Koesoema, 2007: 112) berpendapat bahwa "untuk memahami pendidikan karakter merupakan sebuah sistem pembinaan dan pembentukan untuk menciptakan sosok pribadi pemimpin yang akan membawa masyarakat pada suatu kebaikan dan keadilan.” Ellen G. White dalam Sarumpaet (dalam Muhdar, 2013: 116) mengemukakan bahwa "Pengembangan karakter adalah usaha paling penting yang pernah diberikan kepada manusia. Baik dalam pendidikan rumah tangga ataupun dalam sekolah, orang tua dan guru tetap sadar bahwa pembangunan tabiat yang agung adalah tugas mereka."

\section{Aspek-Aspek Pendidikan Karakter}

Koesoema (2007:

mengemukakan bahwa pendidikan karakter sebagai pedagogi memberikan tiga matra penting setiap tindakan edukatif maupun campur tangan internasional bagi kemajuan pendidikan. Matra itu yaitu sebagai berikut: a. Matra individu, matra individu dalam pendidikan karakter menyiratkan dihargainya nilai-nilai kebebasan dan tanggung jawab. Nilai-nilai inilah yang menjadi prasyarat utama sebuah perilaku bermoral. Yang menjadi subjek bertindak dan subjek moral adalah pribadi itu sendiri.

b. Matra sosial, matra sosial mengacu pada corak relasional antara individu dengan individu lain atau dengan lembaga lain yang menjadi cerminan kebebasan individu dalam mengorganisir dirinya sendiri.

c. Matra moral, matra moral menjadi jiwa yang menghidupi gerak dan dinamika masyarakat sehingga masyarakat tersebut menjadi semakin berbudaya dan bermartabat.

Ada beberapa nilai yang dianggap perlu dalam untuk dijadikan fokus pendidikan karakter. Menurut Deklarasi Aspen (dalam Mundiri, 2012: 42) dihasilkan enam nilai etik utama (core ethical values) yang disepakati untuk diajarkan dalam sistem pendidikan karakter, yaitu: (a) dapat dipercaya (trustworty) meliputi sifat jujur (honesty) dan integritas (integrity), (b) memperlakukan orang lain dengan hormat (treats people with respect), (c) bertanggung jawab, (d) adil (fair), (e) kasih sayang (caring), dan (f) warga negara yang baik (good citizen). 
Strategi Pendidikan Karakter

Strategi dalam pendidikan karakter menurut Lestari (2013: 5455) dapat dilakukan melalui sikapsikap berikut ini:

a. Keteladanan Orang tua harus menjadi figur yang ideal bagi anak-anaknya dan harus menjadi panutan yang bisa mereka andalkan bagi anak-anak dalam mengarungi kehidupan.

b. Penanaman disiplin Disiplin pada hakikatnya adalah suatu ketaatan yang sungguhsungguh yang didukung kesadaran untuk menunaikan tugas kewajiban serta berperilaku menurut aturan atau tata kelakuan yang seharusnya berlaku dalam suatu lingkungan tertentu.

c. Pembiasaan

Anak akan tumbuh dalam lingkungan yang mengajarinya dan merupakan sesuatu kebiasaan yang dihadapi setiap hari. Terbentuknya karakter memerlukan proses yang relatif lama dan terus menerus maka pembiasaan harus dilakukan.

d. Menciptakan suasana yang kondusif

Lingkungan dapat dikatakan merupakan proses pembudayaan anak yang dipengaruhi kondisi yang setiap saat dihadapi dan dialami anak.

e. Integrasi dan internalisasi.

Pendidikan karakter harus terintegrasi dan terinternalisasi dalam segala aspek kehidupan.

\section{Tanggungjawab Keluarga TKW terhadap Pendidikan Anak}

Djamarah

(2004:16)

mendefinisikan keluarga sebagai "sebuah institusi yang terbentuk karena ikatan perkawinan. Di dalamnya hidup bersama padangan suami istri secara sah karena pernikahan." Nurihsan (2009: 99) menyatakan bahwa "keluarga merupakan sistem sosial yang alamiah, berfungsi membentuk aturan-aturan, komunikasi, dan negosiasi di antara para anggotanya." Ketiga fungsi keluarga ini mempunyai sejumlah implikasi terhadap perkembangan dan keberadaan para anggotanya. Keluarga melakukan suatu pola interaksi yang diulang-ulang melalui partisipasi seluruh anggotanya.

\section{Pengertian TKW}

Tenaga Kerja Wanita adalah (TKW) setiap wanita yang mampu melakukan pekerjaan, baik di dalam maupun di luar hubungan kerja, guna menghasilkan sesuatu yang berupa barang atau jasa untuk memenuhi kebutuhan masyarakat. Dalam penelitian ini, TKW merupakan tenaga kerja Indonesia (TKI) yang bekerja di luar negeri. Menurut Undang-Undang No. 39 Tahun 2004 tentang Penempatan dan Perlindungan Tenaga Kerja Indonesia di Luar Negeri, pasal 1, dinyatakan 
bahwa "Tenaga Kerja Indonesia yang selanjutnya disebut dengan TKI adalah setiap warga negara Indonesia yang memenuhi syarat untuk bekerja di luar negeri dalam hubungan kerja untuk jangka waktu tertentu dengan menerima upah."

Undang-Undang No. 13 Tahun 2003 tentang Ketenagakerjaan, pasal 1 menyebutkan bahwa "Tenaga kerja adalah setiap orang yang mampu melakukan pekerjaan guna menghasilkan barang dan/atau jasa baik untuk memenuhi kebutuhan sendiri maupun untuk masyarakat." Oleh karena itu tenaga kerja sedemikian pentingnya bagi kehidupan bangsa dan merupakan faktor yang menentukan mati hidupnya bangsa itu sendiri, baik fisik maupun kulturil maka perlu diadakan peraturan yang sebaik-baiknya yang dimulai sebelum orang menjadi tenaga kerja sampai ia meninggal dunia.

Peran perempuan dalam ekonomi rumah tangga semakin penting sejalan dengan menurunnya peranan sektor pertanian dalam perekonomian desa. "Keterlibatan perempuan dalam kegiatan ekonomi keluarga dipengaruhi oleh beberapa faktor.
Pertama, tekanan ekonomi. Kedua, lingkungan keluarga yang sangat mendukung dalam bekerja. Ketiga, tidak ada peluang kerja lain sesuai dengan ketrampilannya" (Abdullah dalam Sosan, 2010: 99). Nashih Ulwan dalam Djamarah (2004: 29) membagi tanggung jawab orang tua dalam mendidik bersentuhan langsung dengan “(1) Pendidikan iman, (2) Pendidikan moral, (3) Pendidikan fisik, (4) Pendidikan rasio/akal, (5) Pendidikan kejiwaan, (5) Pendidikan sosial, dan (6) Pendidikan seksual."

\section{METODE PENELITIAN}

Penelitian ini dilaksanakan di Desa Nglandung, Kecamatan Geger Kabupaten Madiun. Penelitian ini dilaksanakan mulai bulan September 2015 sampai dengan Januari 2016.

\section{Pendekatan dan Jenis Penelitian}

Penelitian ini menggunakan pendekatan kualitatif. Menurut Bogdan dan Taylor (dalam Moleong, 2010: 4) metode kualitatif adalah prosedur penelitian yang menghasilkan data deskriptif yang berupa kata-kata tertulis atau lisan dari orang-orang dan perilaku yang diamati. Jenis penelitian ini 
merupakan penelitian deskriptif Kabupaten Madiun. Data yang kualitatif, yaitu penelitian yang diperoleh peneliti secara tertulis terbatas pada usaha-usaha yang adalah dokumen atau arsip dari mengungkapkan suatu masalah atau lembaga pemerintahan Desa keadaan atau peristiwa sebagaimana Nglandung berupa data monografi adanya sehingga bersifat sekedar mengungkapkan fakta (fact finding).

\section{Sumber Data}

Data yang digunakan dalam penelitian ini meliputi data primer dan data sekunder. Sumber data primer diperoleh peneliti melalui wawancara dengan responden atau pengamatan. Subyek sebagai sumber data primer dalam penelitian ini adalah keluarga TKW atau orang tua pengganti yang memberikan pendidikan karakter pada anak dalam keluarga baik itu ayah, kakak, atau kerabat atau anggota keluarga dan juga anak pada keluarga TKW di Desa Nglandung, Kecamatan Geger Kabupaten Madiun. Untuk menambah kelengkapan data yang dibutuhkan, peneliti juga melakukan wawancara dengan kepala desa dan perangkat desa serta tokoh masyarakat di Desa Nglandung, Kecamatan Geger Kabupaten Madiun. Data sekunder berupa data-data tertulis mengenai kondisi sosial, budaya dan ekonomi Desa Nglandung, Kecamatan Geger desa tahun 2015 dan dokumen lain untuk menunjang data penelitian yaitu data tertulis mengenai sejarah Desa Nglandung, Kecamatan Geger Kabupaten Madiun.

\section{Teknik Pengumpulan Data}

Terdapat beberapa teknik pengumpulan data yang dapat digunakan dalam suatu penelitian. Pemilihan teknik pengumpulan data harus relevan dengan kebutuhan data penelitian. Pada penelitian ini, teknik pengumpulan data yang digunakan meliputi wawancara, observasi, dan dokumentasi. Teknik wawancara dilakukan dengan cara mengajukan pertanyaan langsung kepada informan, khususnya terkait dengan pendidikan karakter anak pada keluarga TKW, strategi dalam menanamkan pendidikan karakter, juga hambatan-hambatan dalam menanamkan pendidikan karakter anak pada keluarga TKW. Dalam penelitian ini menggunakan metode observasi langsung yaitu pada masyarakat Desa Nglandung, 
Kecamatan Geger Kabupaten

Madiun. Peneliti melakukan observasi ini untuk memperoleh data yang lengkap dan rinci mengenai pelaksanaan pendidikan karakter anak pada keluarga TKW di Desa Nglandung, Kecamatan Geger Kabupaten Madiun.

\section{Teknik Analisis Data}

Menurut Sugiyono (2015: 89) analisis data adalah proses mencari dan menyusun secara sistematis data yang diperoleh dari hasil wawancara, catatan lapangan, dan dokumentasi, dengan cara mengorganisasikan data ke dalam kategori, menjabarkan ke dalam unit-unit, melakukan sintesa, menyusun ke dalam pola, memilih mana yang penting dan yang akan dipelajari, dan membuat kesimpulan sehingga mudah difahami oleh diri sendiri maupun orang lain. Penelitian ini menggunakan teknik analisis data yang bersifat kualitatif, yaitu data yang diperoleh dari hasil wawancara, observasi, dan dokumentasi serta dikumpulkan dan dikelompokkan berdasarkan indikator-indikator yang ada, serta berdasarkan fakta-fakta, dan juga pada pemikiran-pemikiran yang kritis untuk memperoleh hasil yang berbobot. Oleh karena itu, dalam melakukan analisis data digunakan teknik analisis deskriptif. Teknik ini dilakukan dengan mendeskripsikan data-data di lapangan, data tersebut dianalisis dan disimpulkan.

\section{HASIL PENELITIAN}

\section{Penanaman Nilai-Nilai Pendidikan} Karakter Anak Pada Keluarga TKW di Desa Nglandung, Kecamatan Geger Kabupaten Madiun

Pada aspek religius, diketahui bahwa anak-anak sudah diajari untuk meyakini keberadaanya adalah karena adanya Tuhan YME, sehingga dalam agama Islam untuk mengungkapkan rasa syukur salah satunya adalah dengan melakukan shalat. Berdasarkan hasil wawancara anakanak pada keluarga TKW di Desa Nglandung sudah menyadari hal itu, bagi anak-anak yang sudah besar sekitar sudah mempunyai kesadaran sendiri untuk melaksanakan sholat. Anak yang masih kecil masih butuh pembinaan dari orang tua yaitu dengan menyuruh anaknya untuk sholat.

Anak yang masih kecil belum menyadari pentingnya beragama dan menjalankan kewajiban beragama, 
sehingga mereka masih butuh untuk mendapat bimbingan dari keluarga. Seharusnya keluarga yang pertama kali menanamkan pendidikan agama karena menyangkut hubungan manusia dengan Tuhannya. Bapak atau saudara di rumah perlu memberikan pemahaman agama dengan memberikan pengarahan tentang apa yang baik atau tidak baik, selain itu seharusnya keluarga juga yang pertama kali mengajari anak untuk melaksanakan ibadah. Menanamkan pemahaman agama sebaiknya sejak dini, sehingga anak akan masih ingat juga mudah untuk mengajarinya.

Keteladanan dari ayah, seperti melaksanakan sholat berjamaah bersama anaknya, maka dalam hal ini keteladanan dari orang tua sudah ada. Hal ini ditunjukkan dengan adanya temuan penelitian bahwa orang tua atau saudara dari anak keluarga TKW tidak hanya menyuruh anak untuk melakukan sholat, tetapi juga dengan keteladanan yaitu mencontohkan dengan perbuatan nyata dari ayah/pengasuh sendiri untuk melakukan shalat, khususnya dengan mengajak anak untuk shalat berjamaah.
Pendidikan karakter pada anak juga dapat dilakukan melalui pemberian tanggung jawab. Dalam mendidik anak sehingga mempunyai tanggung jawab salah satunya adalah dengan memberikan anak tugas. Pemberian tugas ini bertujuan agar anaknya memelaksanakan dan bertanggung jawab terhadap apa yang ditugaskan kepadanya. Dari pengamatan peneliti, keluarga TKW yang mempunyai anak laki-laki tidak membebankan tanggung jawab atau tugas kepada anak laki-lakinya. Pekerjaan rumah seperti mencuci piring, menyapu dan mengepel lebih sering diberikan kepada anak perempuan.

Pemberian tugas rumah kepada anak laki-laki sebenarnya tidak ada salahnya karena hal tersebut melatih kemandirian dan tanggung jawab anak kelak sebagai bekal hidup dalam keluarga, karena tidak selamanya peran domestik dipegang oleh perempuan. Dalam hal ini ada ketidakpercayaan kepada anak untuk melakukan pekerjaan rumah. Seharusnya anak diajari mulai dari kecil, tentu saja hal itu membutuhkan proses yang panjang, karena anak butuh untuk belajar. Seharusnya 
meskipun tidak bersih dalam hal mencuci, ayah atau saudara dari anak keluarga TKW membiarkan anak untuk melakukan tugas tersebut, karena hal itu merupakan proses dari pembelajaran. Dengan tidak memberikan pekerjaan rumah kepada anak, hal ini pula menyebabakan anak tidak bisa mandiri. Cara mengajari bertanggung jawab lainnya adalah dengan mengajari anak menabung, hal ini bertujuan agar anak dapat mengelola keuangan sendiri. Anak diberi tanggung jawab dalam mengelola uang sendiri selain mengajari anak untuk berhemat juga mengajari anak untuk dapat mengontrol pengeluaran. Anak yang diberi uang khusus untuk menabung bisa bertanggung jawab untuk menabungkan uangnya, dan bukan tidak bertanggungjawab dengan menjajakan uang tersebut. Anak yang tidak mendapat uang khusus menabung dapat menyisihkan uang jajan tersebut dapat belajar berhemat.

Pola pendidikan yang diberikan kepada anak tidaklah konsisten. Anak diajari untuk menabung, tetapi di sisi lain mereka juga dimanjakan oleh uang dengan memberi uang tambahan setelah pulang sekolah. Hal ini akan mengakibatkan tidak maksimalnya pendidikan yang diberikan orang tua. Pada beberapa responden, diketahui terdapat bapak yang selalu menuruti atau memenuhi permintaan anak ketika mereka meminta sesuatu. Pada umumnya, suami TKW mengaku selalu menuruti keinginan anak supaya anak tidak rewel. Selalu memenuhi permintaan anak akan mengakibatkan anak menjadi manja dan menjadi penuntut. Seharusnya ayah tidak memanjakan anak untuk selalu menuruti keinginan anaknya.

Mengajari anak tanggung jawab akan menimbulkan sikap peduli pada anak. Sikap tanggung jawab yang ditanamkan kepada anak adalah contohnya yaitu dengan memberikan pekerjaan rumah. Pada keluarga TKW di desa Nglandung anak-anak perempuan diberi tugas untuk melakukan pekerjaan rumah. Disiplin dalam penelitian ini dimaksudkan adalah suatu sikap yang menunjukan ketaatan terhadap ketentuan yang sudah disepakati bersama baik oleh keluarga maupun oleh masyarakat lingkunganya. Agar anak menjadi pribadi yang disiplin tentunya orang tua harus bekerja keras dan membiasakan anak mengendalikan 
diri dan berusaha menepati waktu. Idealnya orang tua harus membiasakan anak-anaknya berdisiplin dari hal-hal yang sederhana yaitu mentaati kewajiban anak dalam keluarga.

Pada keluarga TKW menerapkan disiplin disini khususnya mengenai pengaturan waktu bermain dan pergaulan anak-anaknya. Pada beberapa ayah dari anak keluarga TKW menyatakan bahwa tidak membatasi pergaulan anaknya, karena anaknya hanya bermain dengan teman sekelasnya saja. Pada umumnya keluarga TKW ayah atau pengasuh membebaskan anak untuk bergaul, tetapi bukan berarti ayah tidak melakukan pengawasan terhadap anaknya. Dari pengamatan dan hasil wawancara menunjukan bahwa responden tidak mengatur bagaimana anaknya harus bermain, dengan siapa harus bermain, tetapi yang pasti anaknya masih berlaku baik dan tidak melakukan penyimpangan dan melakukan hal-hal yang merugikan.

Beberapa hasil wawancara menunjukkan bahwa mengenai kedisiplinan untuk bangun pagi, telah dicontohkan oleh bapak mereka. Hasil wawancara menunjukkan bahwa ada keteladanan dari orang tua untuk bangun lebih pagi juga keteladanan dalam melaksanakan sholat subuh. Ayah atau saudara juga telah memperhatikan anak untuk belajar. Anak-anak belajar hanya kadang-kadang yaitu ketika ujian semester atau ujian nasional tiba. Dari uraian di atas dapat disimpulkan bahwa penanaman kedisiplinan anak sudah maksimal. Hal itu terlihat dari adanya pengaturan terhadap anak mengenai pengaturan waktu anak untuk belajar, bermain dan menonton TV. Kebanyakan anak hanya menghabiskan waktu untuk bermain dan menonton TV. Selain itu, juga sudah ada keteladanan dari orang tua.

Mandiri berarti dapat memecahkan persoalan atau kepentingan sendiri dengan penuh tanggung jawab. Kemandirian pada seseorang sangat mutlak diperlukan, oleh sebab itu sikap kemandirian harus dibiasakan pada anak sedini mungkin. Kemandirian penting agar membentuk karakter, sehingga anak tidak terlalu menggantungkan diri pada orang lain, manusia pada saatnya pasti akan terpisah dengan keluarganya dan harus mampu hidup sendiri tanpa bantuan orang lain. 
Salah satu kebanggaan dambaan setiap orang tua adalah memiliki anak-anak mandiri. Kemandirian dalam aspek berpikir ,ataupun dalam tindakan sehari-hari merupakan suatu sikap yang diharapkan orang tua. Meskipun demikian, kemandirian bukanlah suatu hal yang akan terbentuk dengan sendirinya dalam jiwa anak-anak. Kemandirian bukanlah suatu hal yang terjadi secara instan, melainkan hasil suatu proses yang membutuhkan waktu.

Jadi secara umum anak pada keluarga TKW sudah punya kemandirian. Anak-anak pada keluarga TKW lebih cakap ketika ditinggal ibunya, karena mau tidak mau karena keadaan mereka harus bisa melakukan dan memenuhi kebutuhan pribadinya sendiri. Hal tersebut terjadi karena ayah tidak terlalu cakap dan telaten dalam mengurus anak. Berbeda ketika ada ibunya, bagi keluarga yang Istrinya sudah berangkat lebih dari dua kali ke luar negeri mengaku kalau ada ibunya anak-anak lebih dimanjakan, begitu pula anak-anak lebih manja kepada ibunya. Hal itu terjadi karena waktu yang ditinggalkan ibu untuk anaknya selama bekerja, bisa digantikan ketika kehadiran ibu di rumah sebelum berangkat lagi.

Kemandirian adalah kemamapuan untuk melakukan tugas atau kegiatan sehari-hari sendiri atau dengan sedikit bimbingan, sesuai dengan tahapan perkembangan dan kapasitasnya (Lie, 2004: 2). Anakanak pada keluarga TKW di Desa Nglandung pada umumnya sudah mempunyai kemandirian. Mereka dituntut lebih mandiri daripada keluarga yang ibunya bekerja di rumah. Anak-anak yang ibunya berada di rumah tentu saja segala keperluan pribadinya dilayani, tetapi pada anak yang ibunya bekerja menjadi TKW harus bisa mengerjakan segalanya sendiri. Anak yang masih kecil kadang-kadang ketika makan masih di suapi, atau anak yang baru menginjak kelas 1 SD masih didandani ibunya ketika akan berangkat sekolah seperti memandikan, memakaikan baju dan memakai sepatu. Tetapi anak TKW yang ditinggalkan ibunya sudah bisa melayani dirinya sendiri. Kadangkadang ayah tidak begitu telaten dalam mengurus anak. dalam hal-hal seperti menyuapi, memandikan, atau mendandani anak, sehingga anak 
pada keluarga TKW dituntut lebih mandiri karena ibunya tidak ada.

Kepedulian yang diajarkan oleh ayah keluarga TKW pada anaknya adalah yaitu dengan mengajarkan tanggung jawab pada anaknya, sehingga menimbulkan kepedulian pada sesama. Seperti yang telah diuraikan di atas bahwa pemberian tanggung jawab yang dilakukan keluarga TKW adalah dengan memberikan pekerjaan rumah pada anak. Ketika ayah sibuk bekerja anak diberi tanggung jawab untuk melaksanakan pekerjaan rumah, sehingga anak mengerti bahwa ayahnya juga sedang mencari nafkah pulang kerja tentu capek kalau ayah masih juga harus mengerjakan pekerjaan rumah dan anak-anak peduli sehingga sudah punya kesadaran sendiri untuk melakukan pekerjaan rumah dengan tujuan meringankan pekerjaan ayahnya.

Karakter lainnya yang perlu dimiliki oleh seorang anak adalah sikap peduli. "Caring atau peduli di sini meliputi sikap saling menghormati, menghargai. Kehidupan masyarakat yang kompleks perlu untuk saling menghormati dan menghargai"
(Hidayatullah, 2010: 34). Mengajari anak untuk mengasuh adiknya juga akan menimbulkan kepedulian, hal ini selaras dengan pendapat Lee (2004: 74) yang menyatakan bahwa "mengajak anak yang lebih besar untuk menjaga adiknya memberinya kesempatan untuk menjadi seseorang yang tidak hanya mementingkan dirinya sendiri saja." Mengajarkan anak berbuat baik terhadap sesama manusia dan suka tolong menolong.Kepedulian yang sudah dimiliki anak TKW di Desa Nglandung adalah ditunjukkan dengan mencurahkan perhatian ketika anggota keluarga mereka sakit. Mereka tanggap dan mengerti apa yang harus mereka lakukan baik itu memberi bantuan dengan memijat, atau membelikan obat.

\section{Strategi yang Dilakukan dalam} Memberikan Pendidikan Karakter Anak pada Keluarga TKW di Desa Nglandung, Kecamatan Geger Kabupaten Madiun

Penanaman pendidikan karakter pada anak keluarga TKW memerlukan diperlukan strategi atau cara agar nilai tersebut dapat dilaksanakan dengan baik dalam 
kehidupan oleh anak. Keluarga dapat memberikan pengertian mengenai pendidikan karakter tersebut yaitu dengan cara memberikan pembelajaran, pembiasaan, dan keteladanan. Hal ini sesuai dengan pendapat Lestari (2013: 54-55) bahwa "strategi dalam pendidikan karakter dapat dilakukan melalui sikap-sikap pembelajaran, keteladanan, dan pembiasaan."

Berdasarkan hasil wawancara dengan anak-anak dari keluarga TKW diketahui bahwa anak-anak dari keluarga TKW sudah diajari beribadah oleh orangtuanya. Selain dari orang tua, pembelajaran tentang keyakinan beragama juga diperoleh dari guru, sekolah, dan orang-orang terdekat yang ada di sekitarnya. Anak juga sudah dilatih peduli kepada sesama melalui berbagai tindakan yang dapat dilakukan dalam berinteraksi dengan orang-orang yang ada di dekatnya. Misalnya, berbagi dengan teman atau membantu saudara dan teman yang membutuhkan bantuan.

Pendidikan karakter harus dilakukan melalui keteladanan dari orang tua. Menurut hasil wawancara dengan anak-anak yang orang tuanya menjadi TKW, ayah atau anggota keluarga yang lain selalu memberi contoh atau teladan tentang perilaku yang baik bagi anak-anak. Hal ini dapat dilihat dari penilaian anak-anak terhadap karakter ayah masingmasing serta kebersamaan yang dijalani setiap anggota keluarga selama beraktivitas, khususnya di rumah. Keteladanan untuk anak dapat dilakukan melalui beragam cara. Orang tua perlu memberikan teladan bagi anak-anaknya melalui berbagai kegiatan, seperti rajin beribadah, mengerjakan sesuatu dengan tepat waktu, segera bangun pagi, bekerja giat dan menjaga sikap baik di depan anak-anaknya.

Hambatan-hambatan yang Ada pada Pendidikan Karakter Anak pada Keluarga TKW di Desa Nglandung, Kecamatan Geger Kabupaten Madiun

Orang tua sangat berperan dalam perkembangan anak. Keluarga yang terdiri dari ayah, ibu, dan anak-anak merupakan cerminan dari keluarga yang lengkap. Kehadiran ayah dan ibu sangat berpengaruh terhadap perkembangan anak, adanya ketidak hadiran ibu dalam jangka waktu yang 
lama menyebabkan banyak sekali hambatan-hambatan yang dilalui karena beban pendidikan dalam keluarga yang seharusnya dilakukan oleh ayah dan ibu secara bersamaan dilakukan hanya satu orang saja dan anak kehilangan peran ibu pada masa perkembangannya.

Hambatan internal yaitu hambatan yang berasal dari dalam keluarga itu sendiri, baik itu dari orang yang memberikan pendidikan karakter tersebut ataupun dari dalam diri anak. Pendidikan yang dimiliki oleh pengasuh juga penting dalam mendidik anak. Dengan pengetahuan yang cukup yang dimiliki oleh orang tua akan membantu untuk mendidik anaknya sendiri. Seperti yang telah diuraikan di atas, contohnya adalah dalam menanamkan pendidikan mengenai kepercayaan kepada Tuhan, tidak dilakukan oleh keluarga sendiri, tetapi oleh TPQ/TPA setempat atau kepada guru mengaji. Hal ini karena pengetahuan mengenai agama yang minim sekali dari ayah atau orang tua selaku pendidik. Dalam hal ini, faktor utama dalam memberikan pendidikan karakter kepada anak adalah adanya sikap yang acuh tak acuh atau masa bodoh dari ayah sehingga anak menjadi bersikap seenaknya sendiri. Waktu yang dimiliki ayah untuk anak juga terlalu sedikit. Kedekatan ayah dengan anak yang tidak terlalu intens dan tidak ada waktu untuk bersenda gurau atau bersantai bersama. Hal ini menyebabakan anak menarik diri dari ayah atau pengasuhnya. Hambatan ekternal adalah hambatan yang berasal dari lingkungan atau masyarakat setempat, Interaksi atau pergaulan dengan masyarakat atau teman sepergaulan tentu saja tidak lepas membawa hal yang negatif dan positif. Hambatan yang terjadi dalam memberikan pendidikan kepada anak TKW adalah yang paling utama adalah teman sebaya. Pada masa awal menginjak remaja, anak kadangkadang lebih dekat dengan teman. Hal ini tentu saja sangat berpengaruh terhadap perilakunya contohnya ketika anak disuruh melakukan sholat oleh ayahnya, tetapi karena dihampiri temannya yang tidak sholat, maka ia lebih memilih bermain. Kedua adanya pandangan negatif dari masyarakat tentang keluarga yang istrinya berangkat menjadi TKW. Hal ini berpengaruh terhadap psikologis anak sehingga menyebabkan terhambatnya 
penanaman nilai-nilai karakter pada anak.

Hidup dan bergaul dalam bermasyarakat tidaklah mudah, banyak nilai-nilai dalam masyarakat yang sedikit banyak tentu saja akan berpengaruh terhadap perkembangan dan kepribadian anak. Pergaulan yang baik akan menciptakan suasana kehidupan yang berbudi pekerti luhur, sedangkan pergaulan yang tidak baik justru akan merusak kepribadian dan moral anak, sehingga menimbulkan hal-hal yang tidak diinginkan. Hambatan yang paling utama adalah pengaruh dari pergaulan atau teman sebaya. Masa remaja merupakan masa sulit, dan ingin memberontak. Mereka cenderung lebih dekat dengan teman daripada orang tua. Perilaku anak tentu akan lebih banyak terpengaruh oleh oleh pergaulannya dengan teman-temannya. Tentu saja hal ini lebih sulit lagi dengan tidak adanya kehadiran ibu di rumah, dan waktu ayah yang terbatas karena harus mencari nafkah.

\section{SIMPULAN DAN SARAN}

Berdasarkan data temuan
penelitian dan pembahasan yang
disampaikan sebelumnya, pada
penelitian ini dapat disimpulkan

beberapa hal sebagai berikut. (1) Penanaman nilai-nilai pendidikan karakter anak pada keluarga TKW di Desa Nglandung, Kecamatan Geger Kabupaten Madiun sudah dilaksanakan dengan baik. Pada aspek religius, ditemukan bahwa anak telah mengerjakan sholat dan mengaji yang dilaksanakan di rumah maupun di masjid. Anak sudah memiliki tanggung jawab, meskipun masih terbatas. Rata-rata anak keluarga TKW masih memerlukan bantuan ayah atau keluarga yang lain dalam mengatur waktu, namun anak juga sudah terbiasa dengan jadwal kegiatan yang telah ditetapkan ayah atau keluarga yang lain dan rata-rata sudah memiliki keinginan untuk menepatinya. Anak sudah memiliki kemandirian, tercermin dari anak sudah mengerjakan kegiatan seharihari sendiri atau dengan sedikit bimbingan, sesuai dengan tahapan perkembangan dan kapasitasnya. Anak keluarga TKW memiliki tingkat kepedulian yang beragam, naum ratarata sudah memiliki rasa kepedulian terhadap lingkungan di sekitarnya. (2) Strategi yang dilakukan dalam memberikan pendidikan karakter anak pada keluarga TKW di Desa 
Nglandung, Kecamatan Geger aspek internal adalah tidak adanya ibu Kabupaten Madiun dilakukan melalui pembelajaran, pembiasaan, dan keteladanan. Anak-anak keluarga TKW sudah diajari beribadah oleh orangtuanya. Adapun cara mengajari anak untuk mandiri dapat dilakukan orang tua dengan memberikan tugas dan tanggung jawab kepada anak, diberikan contoh tentang perilaku mandiri, Anak juga sudah dilatih peduli kepada sesama. Ayah atau saudara dari anak-anak keluarga TKW juga membiasakan anakanaknya untuk disiplin melalui pemberian tugas pekerjaan rumah, dan sanksi yang diberikan jika melakukan pelanggaran. ayah atau anggota keluarga yang lain selalu memberi contoh atau teladan tentang perilaku yang baik bagi anak-anak. Hal ini dapat dilihat dari penilaian anak-anak terhadap karakter ayah masing-masing serta kebersamaan yang dijalani setiap anggota keluarga selama beraktivitas, khususnya di rumah. (3) Hambatan-hambatan yang ada pada pendidikan karakter anak pada keluarga TKW di Desa Nglandung, Kecamatan Geger Kabupaten Madiun berasal dari aspek internal dan eksternal. Hambatan dari disamping anak-anak dalam waktu yang lama membuat anak merasa sedih, anak merasakan kangen kepada ibunya, ayah dalam mendidik terlalu tegas bahkan terkadang dengan marah dan terkadang acuh tak acuh atau masa bodoh terhadap anak, serta anak banyak mengalami perubahan perilaku karena kurangnya pembinaan, pendampingan, perhatian, dan kasih sayang dari ibu. Hambatan dari aspek eksternal berasal dari lingkungan masyarakat maupun lingkungan pertemanan atau teman sebaya, khususnya yang berkaitan dengan pergaulan dengan teman, prestasi belajar yang tidak maksimal, dan kesulitan belajar dengan penuh konsentrasi.

Berdasarkan hasil pembahasan dan simpulan, dalam penelitian penelitian ini dapat disampaikan beberapa saran sebagai berikut: (1) Sebaiknya ayah atau kerabat sebagai orang tua bersikap konsisten dalam memberikan pendidikan karakter pada anak. Ayah atau kerabat seharusnya tidak selalu memenuhi tuntutan anak, karena hal itu akan menyebabkan anak menjadi manja. (2) Dalam memberikan pendidikan 
kepada anak sebaiknya ada keteladanan dari orang tua untuk memberikan contoh sikap dan perilaku yang baik. Tidak hanya menyuruh tetapi tidak memberikan contoh seperti melakukan sholat berjamaah bersama, tidak bangun kesiangan untuk berdisiplin, berhemat dan saling menghormati, dengan keteladanan dari pengasuh akan lebih mudah untuk menginternalisasi nilainilai karakter tersebut. (3) Bagi lingkungan di sekitar tempat tinggal anak dari keluarga TKW, sebaiknya turut mengawasi pergaulan anak-anak dari keluarga TKW agar tidak terjerumus ke dalam bentuk-bentuk pergaulan yang negatif dan terhindar dari kenakalan remaja.

\section{DAFTAR PUSTAKA}

Djamarah, Syaiful Bahri. 2004. Pola Komunikasi Orang Tua dan Anak dalam Keluarga Sebuah Perspektif Pendidikan Islam. Jakarta: Rineka Cipta.

Fathurrohman, Pupuh H., AA Suryana, dan Fenny Fatriany. 2013. Pengembangan Pendidikan Karakter. Bandung: Refika Aditama.

Koesoema, Doni. 2007. Pendidikan Karakter Strategi Mendidik Anak di Zaman Global. Jakarta: Grasindo.
Kurniawan, Syamsul. 2013. Pendidikan Karakter. Yogyakarta: Ar-Ruzz Media.

Lestari, Dwi Yuni. 2013. Pembinaan Karakter Siswa di SMP Nasional Pati. Jurnal Ilmiah PPKN IKIP Veteran Semarang. Vol. 1. No. 2. hal. 51-64.

Moleong, Lexy J. 2010. Metodologi Penelitian Kualitatif. Bandung: PT. Remaja Rosdakarya.

Muhdar, H. M. 2013. Pendidikan Karakter Menuju SDM Paripurna. Jurnal Al-Ulum. Vol. 13. No. 1. hal. 103-128.

Mundiri, Akmal. 2012. Pendidikan Teknohumanistik Berbasis Core Ethical Values. Jurnal At-Tajdid. Vol. 1. No. 1. hal. 37-47.

Narwanti, Sri. 2011. Pendidikan Karakter Pengintegrasian 18 Nilai Pembentuk Karakter dalam Mata Pelajaran. Yogyakarta: Familia.

Nurihsan, Achmad Juntika. 2009. Bimbingan dan Konseling. Bandung: Refika Aditama.

Sosan, Isna. 2010. Peran Ganda Ibu Rumah Tangga Yang Bekerja Sebagai Tukang Amplas Kerajinan Ukir Kayu. Jurnal Komunitas. Vol. 2. No. 2. hal. 94-105.

Sugiyono. 2010. Metode Penelitian Pendekatan Kuantitatif. Kualitatif. $R$ \& D. Bandung: Alfabeta. 
Riyayan Dwi Saputro, Pendidikan Karakter Anak Pada Keluarga Tkw ...

_. 2015. Metode Penelitian

Pendekatan Kualitatif.

Bandung: Alfabeta. 